\title{
Pharyngeal Carcinoma
}

National Cancer Institute

\section{Source}

National Cancer Institute. Pharyngeal Carcinoma. NCI Thesaurus. Code C9466.

Carcinoma, predominantly squamous cell, arising from the epithelial cells of the pharynx. 